\section{Birds of the Mixed Woods}

\section{By STUART and MARY HOUSTON}

Mr. Breitung's map of "Saskatchewan Plant Formations" in the AprilJune "Blue Jay" is both interesting and valuable. It not only indicates the type of plants to be found in each section of the province, but because of the interdependence of living things, is equally accurate for bird life as well.

When one is travelling from the "parkland" or "Aspen Grove Section" (which is incidentally the northern part of what bio ogists call the Transition Life Zone), the first clumps of coniferous trees indicate that one is entering the "Mixed Wood Section" or Canadian Life Zone. And what a difference just a few miles can make! For instance, in a short drive between Kelvington and Greenwater Lake, or between Kamsack and Madge Lake, the bird life changes remarkably. Instead of two resident species of warbler (Yellow Warbler and Yellowthroat), there are suddenly over a dozen species to differentiate between -over a dozen new songs to confuse the unmusical ear!

As an exampie, birding at Hudson Bay Junction on June 10 and 11 yielded the following definitely identified species of warblers: Black and White, Nashville, Myrtle, Chestnutside, Ovenbird, Connecticut, Mourning, Yellowthroat and Wilson's Warblers. Though the conifers indicate the southern edge of the "Mixed Wocd Section," the new species are not by any means confined to the coniferous woods. Instead, stands of pop ar and willow that look the same as those many miles to the south, now harbor an interesting new selecticn of birds. In addition to the warblers already mentioned, these include the Olive-sided Flycatcher, Canada Jay, Raven, Hermit and Olive-backed Thrushes, and the Purple Finch. Last but not least, the clear whistle of the White-throated Sparrow is heard everywhere.

As well as the new species encoun-

Plan to attend our

Annual Meeting, Oct. 24

See Last Page tered, others that occur only sparingly in the "Aspen Grove Section" are much cornmoner to the north. The Red-eyed Vireo becomes very common in the Mixed Woods Section, and one hears and sees much more of the Alder Flycatcher, Yellow-bellied Sapsucker, Blue Jay, Sparrow Hawk and American Goldeneye. A Turkey Vulture was noted between Hudson Bay and Armit on June 11. All in all our two days of birding yielded 68 species of birds in the vicinity of Hudson Bay Junction.

\section{BIRD MUSIC}

By CLARISSA STEWART, Fairy Hill, Sask.

They've never studied Harmony;

Their Time is all awry

To connosseurs of music,

But to mortals, such as I

No philharmonic orchestra

With fiddles soaring high

And woodwinds trumpets, cymbals, too

Can with their music vie.

The ark begins at dawning light

His early joyous lay;

"There's nothing here to kick about," Is what he seems to say.

The thrush prolongs at eventide

The day's orchestral grace

With vespers so articulate

"Come here," is what he says.

One after one, the whole day through

Takes up his solo: how

The Catbird, "Canada's Mocking Bird"

Can sing or harshly "Meow"!

The tiny Yellow Warbler

"At his door in the sun"

Shrills "Seek me! Seek me! Seek me!" His song is never done.

The Yelow-breasted Chat puts in

His kettledrum effect.

Such volume from the Jenny Wren

You scarcely would expect.

Even the Black-capped Chickadee

No more does say "chick-a-dee"

But pipes a whistle sweet and clear

From out a leafy tree.

Go plant trees, Prairie Dweller,

If you would hear this band:

They'll glorify your country home

And beautify the land.

They ask you for so little,

No box office have they,

They're on the springtime air "for free,"

Enchanting each new day. 